cerams uz jēgu (tâss respektēšanu). Praktisks kḷūist jautājums: kāā domāt vidi. „Esiet uzmanīgi ar savām domām, tās rīcības sākums (Laodzi)."

\title{
VẼRES
}

Bormane D.K., 199.8, Teritorialitātes humānais spēks vai nespēks, LZA Vēstis. Nr. 4./6. Buttimer A., 1972, Social space and the planning of residental areas, Enviroment and behaviour. $4: 279-318$.

\section{LABAS LAUKSAIMNIECĪBAS PRAKSES (LLP) IZSTRĀDE LATVIJAI}

\section{P.BUŠMANIS, A.KĀRKLIN̦Š, U.OSITTIS, I.TURKA, V.JANSONS, D.LAPIN̦Š, R.SUDĀRS, J. ŠVARCBAHS, I.PLŬME, I.DZALBE}

LLP nosacījumu izstrādes nepieciešamību nosaka:

- Latvijas lauku perspektîvā attīstība;

- ES nitrātu direktīva (EEC/91/676) ar mërķi samazināt un turpmāk novērst üdens piesārņošanu no lauksaimniecības avotiem;

- Baltijas jūras vides aizsardzības Helsinku konvencijas (HELCOM) pielikums III par lauksaimniecības izraisīto piesānnojumu. Tiek prasīts dalībvalstīm izstrāđăt ieviešanas programmu līdz 2002.g. un paredzētos pasäkumus izvērst līdz 2011.gadam.

\section{LLP mērkis:}

- ilgtspējīga lauksaimniecỉbas attīstība Latvijā.

\section{LLP nosacijumu statuss:}

- praktiskās darbības vadlīnijas, lai palīdzētu zemniekiem samazināt saimniekošanas ietekmi uz vidi;

- zemnieki brīvprātīgi izpilda LLP prasības, kuras nav nostiprinātas likumos;

- LLP pakāpeniski tiek izmantota kā bāze zemnieku saimniecību subsidēšanai;

- LLP prasības attīstíbas procesā tiek iekjautas likumos un kḷūst obligätas.

\section{LLP nosacījumos ietvertie trīs līmeni:}

- Latvijas Republikas likumos un noteikumos ietvertas prasības, kuras ir obligătas;

- patreiz aktuālie ieteikumi pareizai saimniekošanai, kuri tuvākā nākotnē var tikt pieņemti kā obligāti;

- nākotnē sagaidāmās prasības, kuru izpildes ievirze jau šodien var dot atdevi. 


\section{LLP projekta izpildes organizāeija}

\section{LATVIJA}

PARTNERI

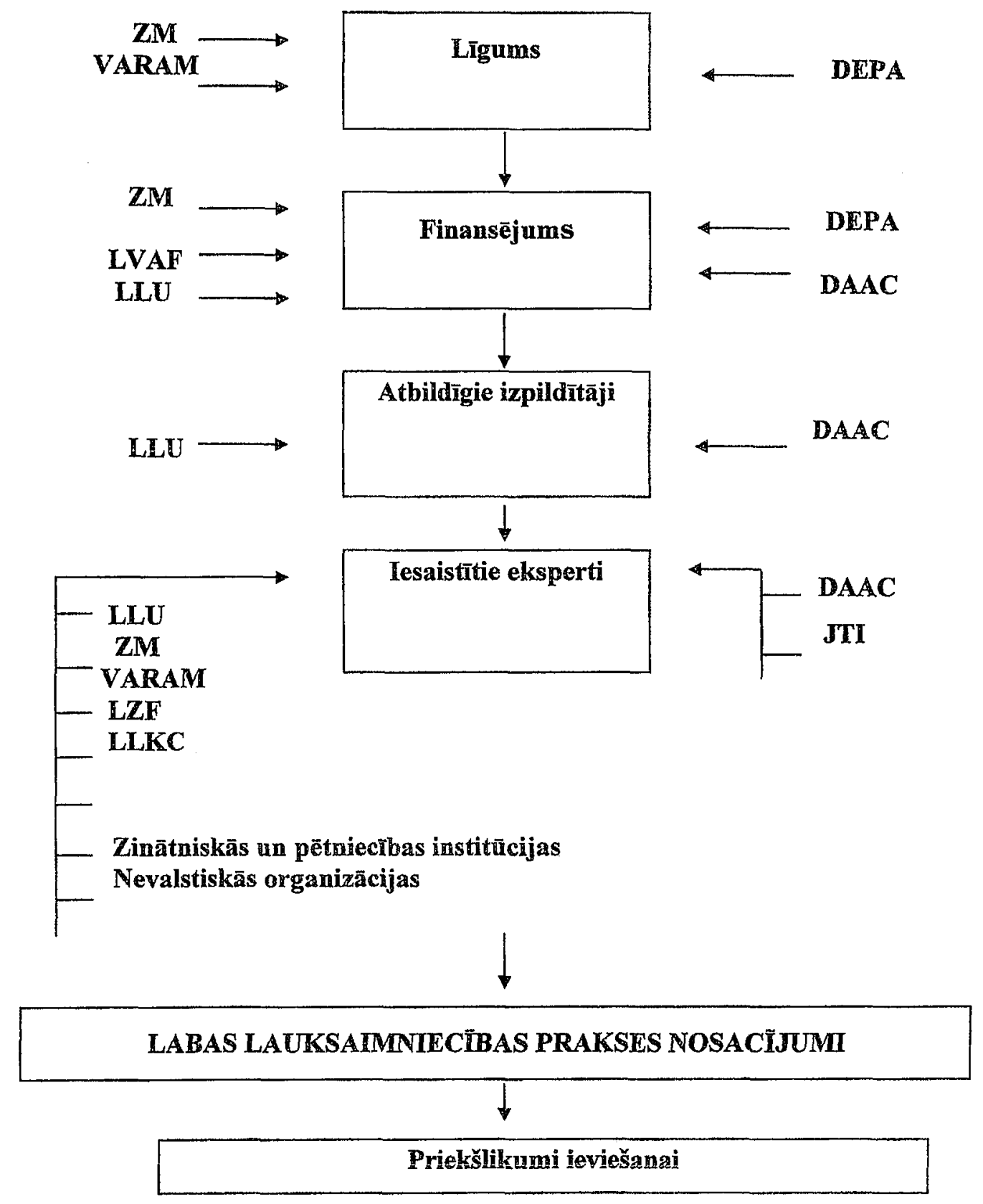

Latvijas LLP nosacījumu sastāys:

1. Augkopība, augsne un mēslošana;

2. Lopkopiba;

3. Kütsmēslu savākšana un uzglabāšana;

4. Augu aizsardzība;

5. Ūdens resursi;

6. Lauksaimniecības sistēmas;

7. Biologiskă daudzveidība un ainava 
Iesaistītās organizācijas LLP nosacījımu izstrādē:

DEPA - Dānijas Vides aizsardzības aǵentūra;

DAAC - Dānijas Lauksaimniecības konsultāciju dienests;

JTI - Zviedrijas Lauksaimniecības mehanizācijas institūts;

ZM - Latvijas Zemkopíbas ministrija;

VARAM - Latvijas Vides aizsardzības un regionālās attīstības ministrija;

LVAF - Latvijas vides aizsardzỉbas fonds;

LLU - Latvijas Lauksaimniecības universitāte;

LZF - Latvijas Zemnieku federācija;

LLKC - Latvijas Lauksaimniecības konsultāciju centrs.

\title{
PROBLEMS WITH RECLAMATION OF ACID LAKES IN THE AREA OF MUŻAKOW LAKES
}

\author{
TADEUSZ CHRZAN \\ Prof., Dr. hab. \\ Technical University of Zielona Góra \\ str. Podgorna $65-246$, Poland \\ Phone: (068) 3254831, Fax: 48683245597
}

\begin{abstract}
In the paper is described actual state of environment after brown-coal exploitation with open-pit and deep-boring methods. The results of recultivationinvestigations are shown, which shown the problems of the strong acid lakesrecultivation. In the paper are also shown the geological and hydrogeological characteristics of the coal deposit area.
\end{abstract}

\section{Introduction}

In the Mużakow-Curve area the open-pit and deep-boring brown coal mining is leaded from the 100 years. As the result of this exploitation is occurred landscape's change - instead the pine-forests we have not covered with plants dump areas, excavations and acid lakes. After the mining activities the anthropogenic Lakeland origins with 100 lakes and 1000 ha of non-recultivated area.

\section{Geological characteristic of the Muzakow-Curve}

\subsection{Geographical localization}

The described areas are located in the neighborhood of polish-germane border in the middle of the Odra-river length. The Mużakow-Curve is a morphological upland in the form of semicircle open to the north. The south-polish glacier, running with the Lausitzian-Nysa ice-marginal valley formed it. The eminencies of the Curve are the end moraine, piled up and elevated to the $153 \mathrm{~m}$ a.s.1. Thrusting glacier caused the folding of the Tertiary sediments. As the result of this process the brown-coal deposits located deep under the ground level were putting up, what is good from the exploitation point of view. Actually the Mużakow-Curve is divided in the middle of length with Lausitzian- 